\title{
Penguatan Pemerintahan Desa Bijeli Kabupaten Timor Tengah Utara Melalui Kegiatan Praktek Kerja Mahasiswa
}

\author{
Yohanes Fritantus ${ }^{1 *}$, Damianus Makun², Martinus Berek ${ }^{3}$, Desiratna Tahoni ${ }^{4}$, \\ Agustinus Tpoy $^{5}$, Neky Julastri Aplugi ${ }^{6}$, Lusia Trinita Naikteas ${ }^{7}$, Ernelinda Ani ${ }^{8}$, \\ Maria Oktaviana Omenu', Yefri D. Kolmusu ${ }^{10}$, Apriana Bano Klau11, Paskalis \\ Abi ${ }^{12}$ \\ 1-12Universitas Timor \\ ${ }^{*}$ Corresponding author \\ E-mail: yfritantus@gmail.com
}

Article History:

Received: 31-08-2020

Revised: 08-02-2021

Accepted: 06-04-2021
Keywords:

\begin{abstract}
Perguruan Tinggi selain melaksanakan Pengajaran dan Penelitian, juga dituntut untuk menyelenggarakan kegiatan pengabdian kepada masyarakat yang merupakan bagian dari pelaksanaan Tri Dharma Perguruan Tinggi. Salah satu model Pengabdian Kepada Masyarakat yang dilaksanakan Perguruan Tinggi Fakultas IImu Sosial dan IImu Politik Universitas Timor yaitu melaksanakan kegiatan Praktek Kerja Mahasiswa (Disingkat: PKM) di Desa Bijeli, Kecamatan Noemuti, Kabupaten Timor Tengah Utara, Provinsi Nusa Tenggara Timur. Kegiatan ini bertujuan memperkuat tugas pelayanan publik, pembangunan dan pemberdayaan masyarakat. Tahapan kegiatan ini yaitu Pertama, survey dan analisis kebutuhan untuk memetakan masalah dan potensi yang ada di desa kemudian dirancang program kegiatan, kedua, pelaksanaan program kegiatan yang sudah dirancang, yaitu pembenahan administrasi profil desa, kegiatan penomoran rumah warga, pendampingan kelompok tani, dan tahapan ketiga, diseminasi laporan Praktek Kerja Mahasiswa. Metode pelaksanaan kegiatan Praktek Kerja Mahasiswa yaitu berpartisipasi di lapangan secara langsung. Hasil kegiatan Praktek Kerja Mahasiswa ini yaitu terciptanya administrasi profil desa yang valid dan lengkap, terwujudnya penomoran rumah penduduk dan peningkatan pemahaman kelompok tani di Desa.

Penguatan, Pemerintah Desa, Praktek Kerja Mahasiswa
\end{abstract}

\section{Pendahuluan}

Lahirnya Undang-Undang No 6 Tahun 2014 tentang Desa memberikan kepastian hukum dan kesempatan bagi Pemerintahan Desa mengelola daerahnya secara otonom (K. P. D. T. dan T. R. I. Desa, 2014). Pada hakekatnya bahwa kehadiran Undang-undang Desa ini memungkinkan kepada masyarakat dan Pemerintah Desa dapat keluar dari segala persoalan yang sering dijumpai di Desa, baik kesenjangan pembangunan, perekonomian, pendidikan, kesehatan serta berbagai kebutuhan dasar lainnya masyarakat di Desa (Hijri et al., 2020; Muzakki, 2020). Desa memiliki potensi yang sangat melimpah, untuk itu apabila dikelola secara baik maka akan menciptakan lompatan kemajuan dan perbaikan di Desa. 
Pengelolaan desa dengan kelimpahan potensi yang ada harus menjadi komitmen dan mendapatkan dukungan dari berbagai pihak, diantaranya ialah dari Perguruan Tinggi. Membangun dari pinggiran merupakan salah satu program Nawa Cita yang merefleksikan pentingnya pelaksanaan pembangunan yang dilakukan secara komprehensif. Untuk mempercepat pertumbuhan desa inovatif, diperlukan peran lembaga kolaboratif dengan Konsep Triple Helix, yaitu Akademisi, Bisnis dan Government (ABG) (Leydesdorff, 2000). Kemajuan sebuah kegiatan ekonomi (bisnis), tidak terkecuali bisnis yang melibatkan masyarakat pedesaan, akan sangat tergantung dari sinergi para aktor ABG tersebut (Suwandana et al., 2015). Hal ini berarti bahwa, Perguruan Tinggi, punya tanggung jawab untuk turut serta membangun kemajuan di desa.

Sesuai dengan Tri dharma Perguruan Tinggi, idealnya perguruan tinggi memiliki kepedulian dan kepekaan terhadap masyarakat (Evaluasi, 2010). Bidang pendidikan dan pengajaran, mengkaji dan mempelajari teori-teori yang disesuaikan dengan kebutuhan masyarakat. Mahasiswa dibiasakan menerapkan konsep yang dipelajari langsung kepada masyarakat. Praktek Kerja Mahasiswa merupakan salah satu model pengabdian kepada masyarakat yang dilaksanakan Perguruan Tinggi. Praktek Kerja Mahasiswa ini perlu diarahkan dalam memecahkan masalah yang dihadapi sehari-hari masyarakat sesuai dengan potensi dan kebutuhan di lapangan. Masalah yang ada di masyarakat tersebut sangat rumit. Di sisi lain, pendekatan top down seringkali kurang mendapatkan respon positif dari masyarakat, karena itu pemecahan masalah dalam masyarakat perlu diupayakan melalui pendekatan pemberdayaan (empowerment), sehingga masyarakat didorong memiliki kemampuan dan kemandirian. Melalui Kuliah Kerja Nyata (KKN) mahasiswa dapat mensinergikan dan mengimplementasikan keilmuan yang ditekuninya dengan kehidupan masyarakat, melatih kepedulian, kepemimpinan, kerjasama, mempelajari kearifan lokal, tatanan nilai, serta norma masyarakat (Anwas, 2011). KKN Tematik Posdaya merupakan sistem yang perlu persiapan, pelaksanaan, bimbingan, pendampingan, monitoring dan evaluasi, dan kegiatan tindak lanjut secara berkesinambungan. Pelaksanaan KKN juga mendorong koordinasi, advokasi, dan kerjasama dengan pihak terkait termasuk melibatkan perusahaan swasta melalui program Corporate Social Responsibility (CSR).

\section{Metode}

Kegiatan pengabdian dalam bentuk Praktek Kerja Mahasiswa ini dilaksanakan di Desa Bijeli, Kecamatan Noemuti, Kabupaten Timor Tengah Utara pada tanggal 01 Juli 2019 dan berakhir pada 15 Agustus 2019. Teknik pengumpulan data yang digunakan pada kegiatan ini terdiri dari (1) Observasi, yaitu pengumpulan data dimana penulis melakukan pengamatan langsung tentang bagaimana proses diupayakan pemerintah desa dalam perencanaan pembangunan dan pemberdayaan 
masyarakat Desa Bijeli; (2) Wawancara, yaitu wawancara merupakan pengumpulan data yang dilakukannya dengan cara berdialog bersama aparat desa dan masyarakat setempat untuk memperoleh data mengenai kepentingan masyarakat desa Bijeli; (3) Dokumentasi, yaitu pengumpulan data yang dilakukan dengan cara memeriksa data, dokumen yang berkaitan dengan pelaksanaan Tugas Pokok dan Fungsi Pemerintahan Desa serta semua dokumen-dokumen yang berkaitan dengan pelaksanaan Tupoksi Pemerintahan Desa, baik berupa Undang-Undang atau Peraturan terkait, Dokumen Rencana Pembangunan di Desa, dokumen-dokumen kependudukan, dan lain-lain.

Secara lebih detail, kegiatan ini dilaksanakan dalam beberapa tahap. Tahapan kegiatan yang dilaksanakan yaitu pertama, tim pengabdian melaksanakan survey dan analisis kebutuhan untuk memetakan potensi dan masalah yang ada di Desa kemudian menyusun rencana aksi untuk mengintervensi penyelesaian masalah dan memaksimalkan potensi yang ada di Desa; kedua: setelah tim pengabdian melaksanakan survey, analisis kebutuhan dan menyusun rencana aksi lalu dilaksanakan; ketiga, dilaksanakan penyusunan laporan Praktek Kerja Mahasiswa dan diseminasi laporan Praktek Kerja Mahasiswa di hadapan Pemerintah Kecamatan dan Pemerintah Desa Bijeli.

\section{Hasil}

Praktek Kerja Mahasiswa tahun 2019 dilaksanakan di Desa Bijeli, Kecamatan Noemuti, Kabupaten Timor Tengah Utara, Provinsi Nusa Tenggara Timur, oleh karena Desa Bijeli dengan didukung oleh potensi sumber daya alam dan kemampuan sumber daya manusia yang baik serta pengelolaan penyelenggaraan pemerintahan desa yang baik, menjadikan Desa Bijeli, Kecamatan Noemuti, Kabupaten Timor Tengah Utara, Provinsi Nusa Tenggara Timur Sebagai "Desa Contoh" tahun 2018 yang menjuarai tingkat kabupaten dan mewakili Kabupaten Timor Tengah Utara ke perlombaan di tingkat Provinsi.

Praktek Kerja Mahasiswa merupakan salah satu penerapan Tri Dharma Perguruan Tinggi. Pelaksanaan Praktek Kerja Mahasiswa (PKM) di Desa Bijeli melalui beberapa tahapan dan menyasar beberapa kegiatan diantaranya, yaitu pelaksanaan survey dan analisis kebutuhan di Desa. Dari hasil survey dan analisis kebutuhan ini kemudian dirancang program kegiatan untuk dapat dilaksanakan di Desa dengan tetap memperhatikan koordinasi dan komunikasi dengan Pemerintah Desa, lalu pada tahapan akhir dilaksanakan kegiatan penyusunan laporan Praktek Kerja Mahasiswa. Berikut diuraikan kegiatan-kegiatan Praktek Kerja Mahasiswa demi memperkuat kapasitas Pemerintah Desa, yaitu (1) kegiatan survey dan analisis kebutuhan, dalam melakukan survey dan analisis kebutuhan terdapat temuan temuan diantaranya kurangnya tertib administrasi Pemerintah Desa, tidak ada kesesuaian antara data profil desa dengan bukti fisik di lapangan, partisipasi 
masyarakat kurang dan tidak ada ketua karang taruna yang definitif. Berdasarkan temuan - temuan hasil survey mahasiswa merancang program kegiatan atau rencana aksi sebagai untuk mengintervensi penguatan pemerintahan desa. Selanjutnya, Tim Pengabdian menguraikan data keadaan demografi dan topografi Desa Bijeli, Kecamatan Noemuti, Kabupaten Timor Tengah Utara diantaranya adalah orbitasi atau jarak pada Tabel 1, jumlah penduduk pada Tabel 2 dan Tabel 3 keadaan sosial.

Tabel 1. Orbitasi/Jarak

\begin{tabular}{lc}
\hline \multicolumn{1}{c}{ Keterangan } & Orbitasi/Jarak \\
\hline Jarak ke kota kecamatan & $1 \mathrm{Km}$ \\
Lama jarak tempuh ke ibukota Kecamatan dengan menggunakan & \\
kendaraan beroda dua & 10 Menit \\
Lama jarak tempuh ke ibukota kecamatan dengan menggunakan & \\
Kendaraan Roda 4 (empat)/ angkutan umum & 10 Menit \\
Jarak ke ibukota Kabupaten/Kota & $14 \mathrm{KM}$ \\
\hline
\end{tabular}

Tabel 2. Jumlah Penduduk

\begin{tabular}{clc}
\hline No & Jenis Kelamin & Jumlah \\
\hline 1 & Laki-laki & 367 \\
2 & Perempuan & 386 \\
3 & Total & 753 \\
4 & Total Kepala Keluarga & 191 \\
\hline
\end{tabular}


Tabel 3. Keadaan Sosial

\begin{tabular}{lc}
\hline \multicolumn{1}{c}{ Tingkat Pendidikan } & Orang \\
\hline Tamat SD/sederajat & 284 \\
Tamat SLTP sederajat & 115 \\
Tamat SLTA sederajat & 145 \\
Tamat S1/Diploma & 57 \\
Putus sekolah & - \\
Buta Huruf & 41 \\
\hline
\end{tabular}

(2) Kegiatan Pembenahan Profil Desa, dimana kegiatan ini dilaksanakan untuk menyiapkan data desa yang lebih baik dan akurat. Kendala yang dihadapi dalam pembenahan profil Desa adalah tidak ada format file profil desa yang baik dan tidak ada kesesuaian data. Tahapan yang dilaksanakan untuk dapat melaksanakan kegiatan ini adalah membuat format profil desa sesuai dengan ketentuan dengan selalu melaksanakan koordinasi dengan Pemerintah Desa dan merekapitulasi ulang data potensi desa. Luaran yang diperoleh dari kegiatan ini adalah Pemerintah Desa memiliki data profil desa yang akurat dan valid.

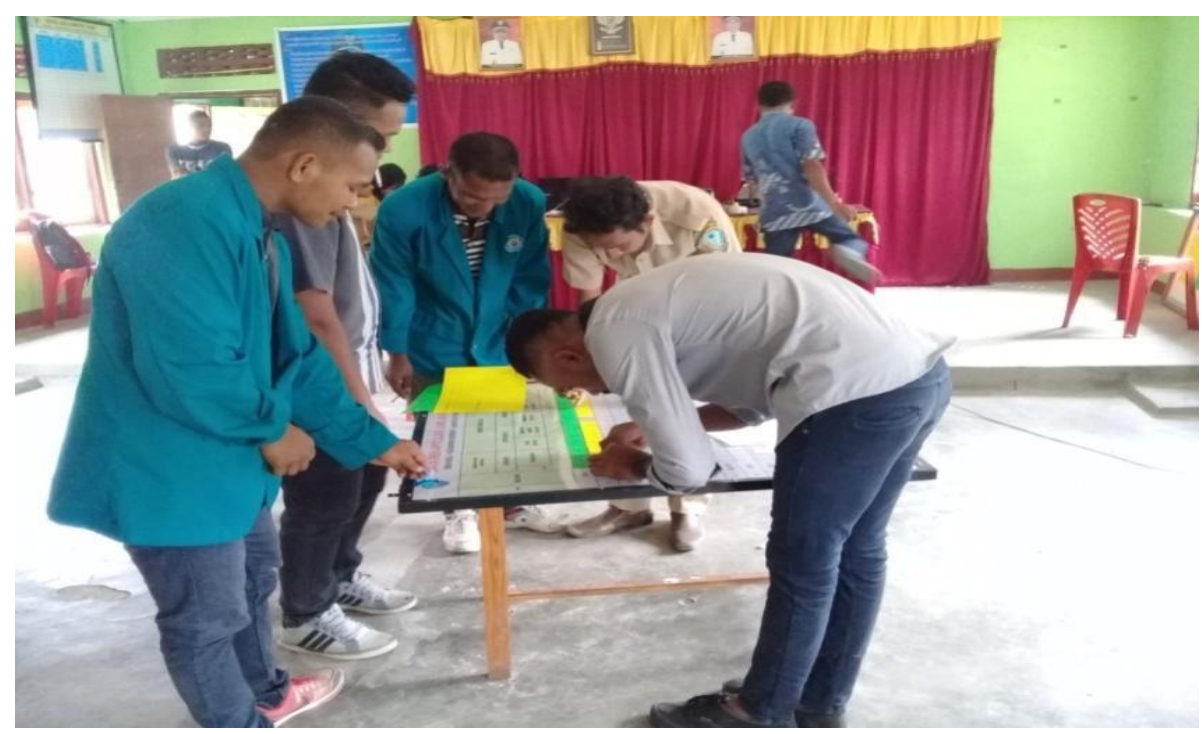

Gambar 1. Pembenahan Profil Desa 
(4) Pembuatan Penomoran Rumah Masyarakat, dimana kegiatan penomoran rumah masyarakat dilaksanakan pada setiap rumah kepala keluarga yang terdata di Desa. Tahapan kegiatan yang dilaksanakan diantaranya adalah melakukan Konsultasi dan koordinasi dengan Pemerintah Desa, Kepala Dusun, hingga RT dan RW untuk mendiskusikan terkait rencana kegiatan ini. Output atau hasil dari kegiatan ini adalah setiap rumah kepala keluarga di desa memiliki papan nomor rumah.

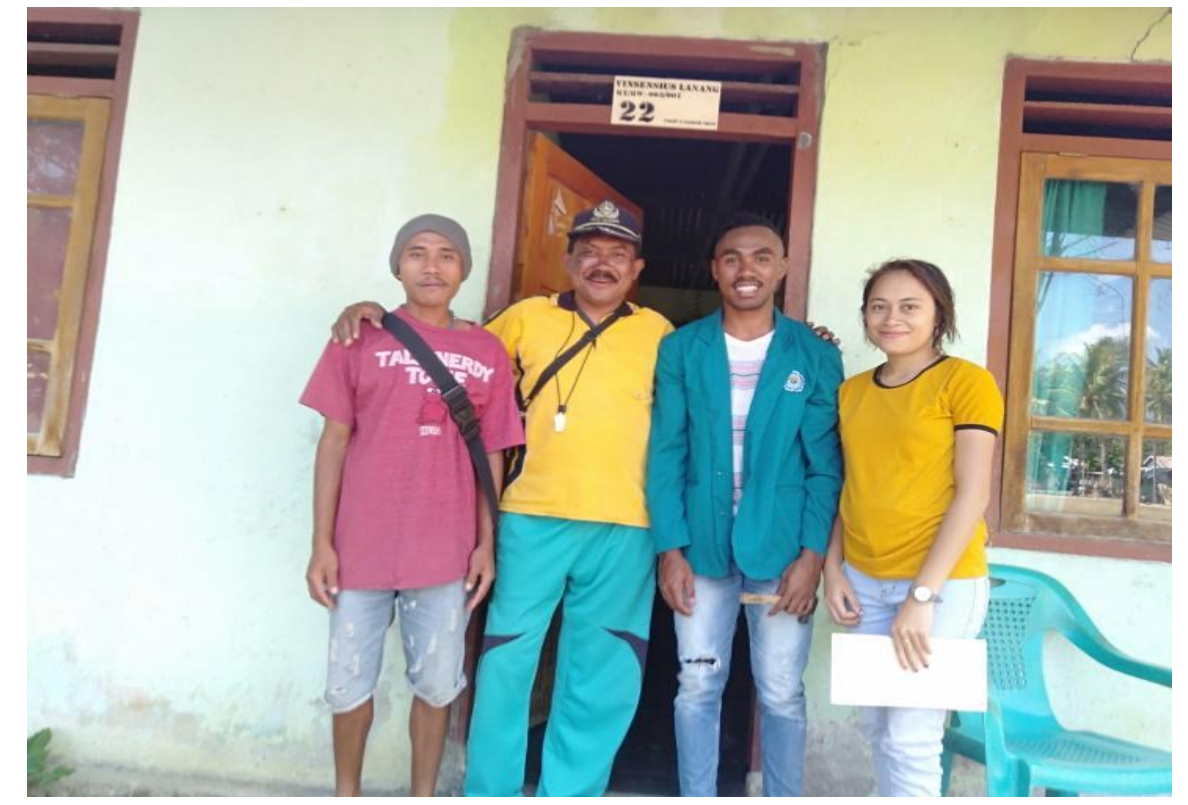

Gambar 2. Penomoran Rumah Warga

(5) Pendampingan Kelompok Tani, dimana kegiatan ini merupakan kegiatan insidental yang dilaksanakan oleh Pemerintah Desa. Untuk itu, mahasiswa diminta untuk berpartisipasi dalam kegiatan tersebut. Kegiatan yang dilaksanakan yaitu bersama masyarakat dan dikoordinir oleh Pemerintah Desa melaksanakan pembersihan lahan pertanian. Yang ditemukan dilapangan yaitu banyak masyarakat tidak memiliki lahan di lokasi Kustanis dan kurang partisipasi masyarakat karena kekurangan air; (6) Penyusunan Laporan dan seminar laporan, dimana kegiatan ini dilaksanakan dalam beberapa rangkaian kegiatan yaitu pada tanggal 11, 12, 13 Agustus 2019 melakukan pembimbingan dengan Dosen Pendamping dan Kepala Desa sebagai penanggung jawab di desa. Kemudian pada tanggal 14 Agustus 2019 bertempat di Aula Kerja Kantor Kecamatan Noemuti Kabupaten Timor Tengah Utara dilaksanakan laporan Praktek Kerja Mahasiswa di Desa Bijeli Kabupaten Timor Tengah Utara diseminarkan di hadapan Dosen Pendamping, Pemerintah Desa, Pemerintah Kecamatan, dan pimpinan Fakultas IImu Sosial dan IImu Politik Universitas Timor. 


\section{Kesimpulan}

Berdasarkan hasil evaluasi uraian kegiatan pelaksanaan praktek kerja mahasiswa di atas maka dapat disimpulkan bahwa pelaksanaan Praktek Kerja Mahasiswa Tahun 2019 di Desa Bijeli berupaya keras dalam melakukan perubahan - perubahan dalam mengisi kekurangan - kekurangan yang ada pada Desa Bijeli dengan menjabarkan program dan kegiatan berdasarkan survey dan analisis kebutuhan di lapangan.

\section{Daftar Referensi}

Anwas, O. M. (2011). Kuliah Kerja Nyata Tematik Pos Pemberdayaan Keluarga Sebagai Model Pengabdian Masyarakat Di Perguruan Tinggi. Jurnal Pendidikan Dan Kebudayaan, 122350.

Desa, K. P. D. T. dan T. R. I. (2014). Undang-Undang Nomor 6 Tahun 2014 tentang Desa.

Evaluasi, P. B. K. D. D. (2010). Pelaksanaan Tridharma Perguruan Tinggi. Direktorat Jenderal Pendidikan Tinggi Departemen Pendidikan Nasional.

Hijri, Y. S., Kurniawan, W., \& Hilman, Y. A. (2020). Praktik Penyusunan Peraturan Desa (Perdes) sebagai Penguatan Desa Tangguh Bencana di Kabupaten Malang. Amalee: Indonesian Journal of Community Research and Engagement, 1(1), 1-11. https://doi.org/10.37680/amalee.v1i01.131

Leydesdorff, L. (2000). The triple helix: An evolutionary model of innovations. Research Policy, 29(2), 243-255.

Muzakki, H. (2020). Produksi Kue Brownies sebagai Upaya Meningkatkan Nilai Ekonomi Singkong di Krajan Blimbing Dolopo Madiun. Amalee: Indonesian Journal of Community Research and Engagement, 1(2), 87-99. https://doi.org/10.37680/amalee.v1i2.303

Suwandana, E., Mutaqin, A. Z., Rostiawati, E., \& Oktaviana, O. (2015). Kajian Penguatan Lembaga Kolaboratif dalam Penguatan Desa Inovatif di Provinsi Banten. National Proceedings of Pertemuan IImiah Tahunan (PIT) Nasional Ke-2 Ikatan Widyaiswara Indonesia (IWI) Provinsi Banten Pandeglang, 453-467. 